\title{
ANTROPOLOGI KEKERASAN AGAMA Studi Pemikiran Jack David Eller
}

\author{
Rohmawati \\ Institut Agama Islam Negeri Tulungagung \\ E-mail: rahma.ringinpitu@gmail.com
}

\begin{abstract}
This article aims to study the anthropology of religious violence in Jack David Eller's perspective. The conclusions are: (1) violence, anthropologically, is not an objective quality of a concept and a judgment, depending on the person who sees it. Some violence is considered good and ordered as rights and obligations; (2) the factors supporting violence are: constituents of cultural violence, integration into groups, identities, institutions, interests, and ideologies; (3) religious violence is practiced in all religions because there are some aspects of violence in religious doctrine; (4) religious violence has various forms: sacrifice, martyrdom, persecution, holy war, ethno-religious conflict, abuse, crime and murder.
\end{abstract}

Key words: Religious Violence, Anthropology, Jack David Eller

\section{Pendahuluan}

Kekerasan dalam masyarakat adalah ciri kemajemukan yang tinggi dalam berbagai konteks faktual seperti geografi, ras, etnik, agama, dan golongan sosialekonomi. Dalam perjalanan sejarah, agama memiliki banyak fungsi dalam masyarakat pluralistik. Secara normatif, agama mengajarkan kerukunan, perdamaian, harmoni dan peradaban. Namun interpretasi terhadap normativitas agama seringkali dijadikan justifikasi tindak kekerasan dengan mengatasnamakan agama. Bahkan sebagian sarjana Barat berpendapat bahwa agama merupakan sumber konflik dan kekerasan. Pandangan ini didukung oleh banyaknya peristiwa kekerasan agama di seluruh dunia.

Jack David Eller adalah seorang guru besar di bidang antropologi di Boston University, Boston, Amerika Serikat. Dengan pendekatan antropologi, Eller menyuguhkan pemikiran yang komprehensif mengenai kekerasan agama yang dituangkan dalam bukunya yang berjudul "Introducing Anthropology of Religion." Eller mengemukakan bahwa sejak awal abad ke21 agama dan kekerasan memiliki hubungan yang tidak bisa diabaikan. Kekerasan tidak dapat dilepas dari "kejelekan" agama dengan mengacu pada adanya pandangan atau pembedaan oleh masyarakat untuk memberi label agama yang jelek dan agama yang baik. Kekerasan yang bersifat keagamaan sangat komplikatif dan untuk memahaminya membutuhkan penyelidikan mendalam. Merujuk pendapat Magnus Ranstorp (2003), seorang ahli terorisme internasional, Eller menjelaskan bahwa jumlah gerakan keagamaan ekstremis di seluruh dunia meningkat tiga kali lipat dari pertengahan 1960-an hingga pertengahan 1990-an. Pada saat yang sama, jumlah kelompok teroris yang terinspirasi agama tumbuh dari nol menjadi sekitar seperempat dari semua organisasi teroris yang dikenal. Pada periode 1970 hingga 1995, kelompok agama menyumbang lebih dari setengah dari total tindakan terorisme dunia - semua ini sebelum terjadinya peristiwa "September Eleven" (9/11) atau "Sebelas September" (Eller, 2007: 218-219).

Jack D. Eller berpandangan bahwa selama ini para ilmuan dalam mengkaji kekerasan agama hanya fokus pada agama Kristen dan Islam, dan sedikit menyinggung 
Yudaisme, jenis kekerasan yang dibahas juga terbatas pada "terorisme" dan "perang suci," serta selalu menghubungkan agama dan kekerasan. Padahal menurut Eller, isu kekerasan agama sangat beragam dan rumit. Pemahaman menyeluruh atas kekerasan yang muncul dari agama membutuhkan kajian agama yang lebih komprehensif. Menurutnya, ada banyak cara untuk memasukkan agama atau mempromosikan kekerasan daripada yang biasanya dipikirkan, dan banyak lagi manifestasi kekerasan semacam itu. Jack D. Eller menunjukkan bahwa setiap contoh kekerasan agama memiliki mitra nonreligiusnya (ada perang suci dan ada perang sekuler), sehingga kekerasan tampak seperti konstruksi sosial yang dilakukan oleh pelaku tertentu dalam kondisi tertentu untuk alasan tertentu.

Dalam artikel ini, penulis mengupas pemikiran Jack D. Eller tentang antropologi agama, khususnya mengenai kekerasan bermotif agama, yang penulis kaji dari bukunya yang berjudul "Introducing Anthropology of Religion." Adapun kajiannya meliputi: (1) antropologi kekerasan, (2) faktor pendukung terjadinya kekerasan, (3) agama sebagai justifikasi kekerasan, dan (4) keragaman kekerasan agama.

\section{Pembahasan}

\subsection{Antropologi Kekerasan}

Mendefinisikan kekerasan secara antropologis adalah sangat rumit. Eller mengemukakan adanya dua problem utama dalam menjelaskan kekerasan. Problem pertama adalah bahwa kekerasan dianggap sebagai sesuatu yang tidak teratur, mengganggu, antisosial. Sebaliknya, antropolog memahami kekerasan sebagai bagian dari masyarakat, dibangun di dalam dan oleh masyarakat, bahkan terkadang sebagai pola pikir dan sikap masyarakat. Dalam pandangan George Simmel, konflik atau kekerasan adalah hubungan sosial, dalam beberapa kondisi dianggap sebagai hal yang positif secara sosial (Simmel, 1955: 20). Sejalan dengan Simmel, Eller juga berpandangan bahwa kekerasan dapat mengintegrasikan dan memotivasi orang, mengklarifikasi dan memperkuat nilai-nilai, dan menguatkan batas-batas kelompok.

Problem kedua, adanya perasaan bahwa kekerasan itu bersifat obyektif, absolut, dan hal yang menyatukan, bahkan mungkin menyangkut kualitas tindakan atau pelaku kekerasan. Menurut Eller, perspektif ini mengarah pada definisi kekerasan yang rapi, yang secara budaya sangat sulit untuk dirancang. Tidak mudah membedakan tidakan kekerasan dengan tindakan nonkekerasan, karena tindakan yang sama dapat dinilai sebagai kekerasan dalam satu konteks dan dinilai bukan kekerasan dalam konteks yang lain (Eller, 2007: 220).

Berdasarkan perbedaan persepsi tersebut, Eller berpendapat bahwa kekerasan bukanlah kualitas obyektif dari sebuah konsep dan penilaian. Pendapat Eller ini senada dengan yang dikemukakan oleh Scheper-Hughes dan Bourgois (2004), bahwa "kekerasan ada di mata orang yang melihatnya." Apa yang merupakan kekerasan selalu dimediasi oleh dikotomi tersurat atau tersirat antara sah atau tidak sah, tindakan yang diizinkan atau disetujui, seperti ketika kekerasan 'sah' dari militer negara dibedakan dengan kekerasan yang dilarang oleh masyarakat atau kaum revolusioner" (Scheper-Hughes dan Bourgois, 2004: 2). Menurut ScheperHughes dan Bourgois, "sebagian besar tindakan kekerasan terdiri dari perilaku yang diizinkan secara sosial, didorong, atau diperintahkan sebagai hak atau kewajiban. Sebagian besar kekerasan bukanlah perilaku menyimpang, tidak dilarang, tetapi sebaliknya didefinisikan sebagai tindakan yang baik dalam pelayanan sosial, ekonomi, dan politik konvensional yang berlandaskan norma" (Scheper-Hughes dan Bourgois, 2004: 5).

Budaya kekerasan yang tumbuh dan berkembang di masyarakat oleh Johan Galtung, sebagaimana dikutip oleh Ahmad Isnaini, diklasifikasikan dalam tiga tipe kekerasan yang ketiganya saling bertalian, yaitu (1) kekerasan langsung, merupakan 
suatu peristiwa; (2) kekerasan struktural, merupakan suatu proses yang mengalami pasang surut; dan (3) kekerasan budaya. Dalam perspektif Galtung, agama sebagai kenyataan sosial dapat masuk ke dalam tiga tipe kekerasan tersebut. Galtung memasukkan agama sebagai bagian dari wilayah yang menjadi basis munculnya kekerasan kultural yang pada gilirannya dapat difungsikan untuk melegitimasi kekerasan langsung dan kekerasan struktural. Agama dalam kapasitasnya sebagai kekerasan budaya dapat disorot pada bagaimana suatu tindak kekerasan langsung dan fakta kekerasan struktural dilegitimasi dan menjadi dapat diterima di kalangan masyarakat (Isnaini, 2014).

\subsection{Faktor Pendukung Terjadinya Kekerasan}

Kekerasan itu terjadi karena ada faktor yang mendukung. Menurut Eller, terdapat beberapa isu yang menjadi faktor pendukung munculnya kekerasan, yaitu konstituen kekerasan budaya, integrasi ke dalam kelompok, identitas, institusi, minat, dan ideologi.

Dalam perspektif antropologis, kekerasan yaitu orang biasa yang dengan sengaja menyakiti orang lain dalam situasi atau budaya tertentu atas perintah otoritas tertentu. Merujuk pada hasil penelitian psikolog sosial Philip Zimbardo (2000), Eller menjelaskan bahwa faktor sosial jauh lebih penting daripada faktor psikologis dalam mempromosikan kekerasan. Secara khusus, ia mengidentifikasi enam faktor yang menyebabkan orang baik melakukan hal buruk: (1) indoktrinasi ke dalam sistem pemikiran yang merasionalisasi atau melegitimasi kekerasan; (2) kepatuhan terhadap otoritas, tanpa menerima perbedaan pendapat; (3) anonimitas dan deindividuasi; (4) difusi tanggung jawab (misalnya, "hanya mengikuti perintah" atau membagi perilaku kekerasan di antara sekelompok orang); (5) eskalasi kekerasan secara bertahap; (6) dehumanisasi musuh atau korban. Dari keenam faktor tersebut, Eller berpandangan bahwa kepatuhan yang buta terhadap otoritas adalah sangat berbahaya. Menurutnya, hal penting untuk melakukan tindakan yang merugikan adalah kurangnya empati bagi calon korban. Dalam empati, kita bisa merasakan penderitaan orang lain di sekitar kita (Eller, 2007: 222).

Menurut Eller, jika manusia memiliki potensi kekerasan sebagai individu, maka potensi itu akan meningkat secara dramatis dalam kelompok. Menurutnya, kekerasan kelompok cenderung lebih banyak daripada kekerasan individu. Mengutip pendapat Freud (1968), Eller menjelaskan bahwa kelompok memiliki perbedaan psikologi tersendiri, yang ditandai dengan meningkatnya emosi dan irasionalitas, meningkatnya rangsangan dan agitasi. Pendapat ini didukung oleh Baumeister yang menyatakan bahwa kekerasan yang dilakukan kelompok cenderung lebih antagonis, persaingan, dan eksploitatif daripada yang dilakukan individu. Seorang individu akan mengadopsi perilaku yang lebih antagonis ketika berhadapan dengan kelompok daripada ketika berhadapan dengan individu lainnya (Baumeister, 2001: 193).

Identitas adalah salah satu faktor pendorong seseorang melakukan kekerasan. Eller mendefinisikan identitas sebagai konstruksi budaya yang kompleks, yang biasanya terdiri dari beberapa elemen, yang semuanya berhubungan langsung dengan kelompok. Identitas tersebut meliputi, pertama, nama, yang terdiri dari bahasa, wilayah, sejarah, agama, ras, atau apa saja yang dimiliki; kedua, nilai atau keyakinan; dan ketiga, interaksi pribadi.

Menurut Eller, di dalam sebuah institusi terkandung nilai-nilai yang mungkin mendorong pada kekerasan atau non-kekerasan. Misalnya institusi keluarga, ada yang diciptakan untuk nir-kekerasan, ada pula yang menjadi tempat utama dalam melakukan atau mengalami kekerasan. Eller juga memandang minat sebagai salah satu faktor pendorong untuk melakukan kekerasan; setiap individu atau kelompok memiliki kepentingan yang ingin diraih. Manusia baik secara individu maupun 
kelompok berlomba-lomba meraih minat atau keinginan mereka. Apabila terjadi ketidaksetaraan atau ketidakadilan dalam kelompok mereka, maka akan muncul persaingan yang berdampak pada konflik yang bisa berubah menjadi kekerasan. Faktor pendorong lainnya bagi individu atau kelompok untuk melakukan kekerasan adalah ideologi. Eller memahami agama sebagai fenomena sosial yang sangat berkontribusi bagi identitas individu dan kelompok (Eller, 2007: 225).

Berdasarkan paparan di atas, tampaknya Eller melihat adanya faktor internal dan eksternal yang mendukung terjadinya kekerasan, di mana faktor-faktor tersebut berkaitan erat dengan kondisi psikologis dan sosio-kultural seseorang atau kelompok yang melakukan kekerasan.

\subsection{Agama Sebagai Justifikasi Kekerasan}

Penjelasan agama tentang kekerasan sama banyaknya dengan agama itu sendiri. Sebagian besar penjelasan mengemukakan bahwa aturan agama akan bergantung pada makhluk, kekuatan, konsep, dan peran khusus yang diikutinya. Salah satu "alasan" umum dilakukannya kekerasan pada diri manusia di dunia adalah manusia itu sendiri. Manusia saling menyakiti dan sering memilih untuk melakukan kekerasan. Dalam tradisi Kristen, kecenderungan manusia seperti ini dikaitkan dengan "kehendak bebas" dan ketidaksempurnaan manusia. Manusia bebas memilih antara untuk "membantu" atau "membahayakan" orang lain, dan tidak jarang manusia lebih memilih "membahayakan" dari pada "membantu" kepada sesama (Eller, 2007: 229).

$$
\text { Mengutip pendapat Mark }
$$

Juergensmeyer (2000), Eller mengelaborasi beberapa elemen yang menciptakan hubungan penting antara agama dan kekerasan, yaitu (1) moralisme transenden yang dengannya tindakan-tindakan seperti itu dibenarkan; (2) intensitas ritual yang mereka lakukan; (3) gambaran religius perjuangan dan transformasi yang mereka kenal dan konsep kosmik perang yang mereka tafsirkan; (4) persepsi bahwa komunitas mereka sedang diserang (Eller, 2007: 227). Wim Beuken dan Karl-Josef Kauschel (Bauken, 2003: xiv-xxv) menyuguhkan sebuah pandangan bahwa kekerasan dengan menggunakan justifikasi agama bisa dilihat dari dua perspektif, yaitu pertama, pembacaan agama tentang hubungan sosial, di mana agama merupakan legitimasi bagi keabsahan perilaku kekerasan karena memiliki fungsi sebagai ideologi. Dalam konteks ini, Musa Asy'ari berpendapat bahwa memahami dan menafsirkan doktrin agama yang kurang tepat merupakan bentuk nyata dari penyebab alasan agama melegitimasi dan menjustifikasi kekerasan (Isnaini, 2014); kedua, agama sebagai faktor budaya identitas.

Kekerasan berbasis agama dijumpai pada semua agama di dunia. Dalam pandangan Eller, agama-agama yang paling kecil dan paling tradisional sekalipun memberi ruang terhadap beberapa bentuk tindak kekerasan. Misalnya, individu yang melanggar perintah agama atau menyangkal/menghujat keyakinan agama dapat dikenakan hukuman. Namun, tidak ada keraguan bahwa agama-agama di dunia memiliki aturan pembenaran yang lebih luas dan terperinci untuk kekerasan dan telah dilakukan pada skala tunggal. Menurutnya, aspek-aspek kekerasan dalam doktrin keberagamaan dan penyalahgunaan doktrin oleh para militan agama untuk membenarkan kekerasan perlu dilakukan penyelidikan. Keduanya sama berpotensi untuk menyebabkan kekerasan. Yang pertama menunjukkan sumbangan agama terhadap aksi-aksi kekerasan dan yang kedua merujuk pada budaya kekerasan yang diciptakan oleh para militan agama (Eller, 2007: 225-229).

Beberapa kasus kekerasan atas nama agama seperti konflik antara suku Hutu dan Tutsi di Afrika, di mana misionaris KristenIslam menemukan masyarakat yang terpecah belah, namun wahyu Kristen yang menang. Kristen telah menghancurkan agama tradisional Rwanda (dengan memuji prajurit suci). Di Sri Lanka, konflik dan kekerasan 
atas nama agama sebagai respon kaum Buddish terhadap sistem pendidikan kolonial dan misionaris Kristen. Konflik dan kekerasan berbasis agama yang terjadi di Amerika Latin, yakni di Guatemala dan Elsavador, merupakan respon terhadap ketidakadilan struktural (Sumbulah, 2005). Selanjutnya, konflik antara Sunni dan Syiah yang menyebabkan pembunuhan ribuan nyawa di berbagai kawasan dunia Islam merupakan konflik antara kedua sekte dalam Islam yang sudah ada sejak ratusan tahun yang lalu.

Hal serupa juga terjadi pada agama Kristen. Kekerasan muncul karena persekusi gereja atas sekte-sekte yang dianggap sesat. Ketika terjadi penaklukan kembali semenanjung Iberia (Spanyol dan Portugis) oleh Raja Ferdinand V dan Ratu Isabela I pada 1492, ratusan ribu umat Islam dan Yahudi dipaksa dengan kekerasan untuk meninggalkan agama mereka dan memeluk Kristen (Abdalla, 2013). Di Indonesia, juga banyak dijumpai tindakan kekerasan yang dilakukan atas nama agama, seperti serangan terhadap gereja, minoritas Muslim (seperti Ahmadiyah dan Syiah) atau non-Muslim (seperti Kristen) yang terjadi di beberapa tempat di Indonesia belakangan ini.

Pada kekerasan agama terdapat dimensi teologis dalam bentuk pembenaran kekerasan itu melalui dalil-dalil keagamaan. Dalam Islam, misalnya, sebuah ayat yang sering dikutip oleh banyak kalangan untuk membenarkan sikap "keras" terhadap mereka yang bukan Muslim adalah Q.S. 48 ayat 29 yang berbunyi: wa al-ladzīna ma'ahū ashiddā'u 'ala-l-kuffar ruhamā'u bainahum - ayat ini menjelaskan dua ciri utama pengikut Nabi Muhammad, yakni bersikap lemah lembut (ruhama $\bar{a}^{\prime}$ ) terhadap sesama Muslim, dan bersikap keras (ashidd $\bar{a}^{\prime}$ ) terhadap orang-orang yang dikategorikan sebagai kafir.

Dalam tradisi Kristen, landasan teologis untuk pembenaran kekerasan dapat ditemukan dalam Perjanjian Lama yang memerintahkan kekerasan terhadap masyarakat lain serta anggota masyarakat yang tidak taat atau tidak percaya. Seperti dalam Bilangan 13: 7-18:

"Dan mereka berperang melawan orang Midian, seperti yang diperintahkan Tuhan kepada Musa; dan mereka membunuh semua lakilaki. Dan anak-anak Israel mengambil semua wanita dari tawanan Midian dan mereka anakanak kecil, dan mengambil jarahan dari semua ternak mereka, dan semua kastil mereka yang baik, dan semua barang mereka. [Musa berkata] Sekarang, bunuhlah semua laki-laki di antara anak-anak kecil, dan bunuhlah wanita yang dikenal manusia dengan tidur bersamanya.Tetapi semua wanita anak-anak, yang belum mengenal seorang pria dengan tidur bersamanya, tetap hidup untuk dirimu sendiri."

Jika kita memahami bunyi ayat atau pasal di atas secara literal, maka seolah-olah tindak kekerasan atas nama agama itu benarbenar direstui dan dibenarkan oleh agama. Padahal agama membolehkan kekerasan adalah dalam konteks tertentu dan untuk tujuan tertentu, sehingga diperlukan pemahaman yang komprehensip terhadap ayat-ayat atau pasal-pasal agama mengenai kekerasan.

\subsection{Keragaman dalam Kekerasan Agama}

Agama dan kekerasan adalah kompatibel, tetapi keduanya tidak identik. Kekerasan merupakan sebuah fenomena dalam eksistensi manusia yang bersifat alamiah, sedangkan agama adalah sesuatu hal yang lain. Namun demikian, tak dapat dihindari bahwa keduanya saling berhubungan. Agama itu kompleks dan modular, sementara kekerasan merupakan salah satu modulnya - tidak universal, tetapi berulang. Sebagai konsep dan modul perilaku, kekerasan sama sekali tidak eksklusif bagi agama. Ada banyak kelompok, institusi, minat, dan ideologi lain yang digunakan untuk mendukung 
kekerasan. Oleh karena itu, kekerasan adalah tidak esensial atau eksklusif bagi agama. Tidak dapat dikatakan juga bahwa kekerasan agama semuanya adalah sama. Ada banyak manifestasi dan motivasi dilakukannya kekerasan atas nama agama (Eller, 2007: 229-230).

Hasil penelitian Eller menunjukkan bahwa kekerasan agama memiliki beberapa bentuk, yaitu pengorbanan, kemartiran/kesyahidan, penganiayaan, perang suci, konflik etno-religius, pelecehan, kejahatan dan pembunuhan.

\subsubsection{Pengorbanan (Sacrifice)}

Kata Sacrifice di dalam bahasa Indonesia disebut dengan pengorbanan, yang memiliki makna "membuat suci." Kata ini berasal dari bahasa Latin yang terdiri dari kata "sacer" yang berarti "untuk suci" atau "suci" dan "facere" yang bermakna "membuat atau melakukan." Eller menjelaskan definisi pengorbanan sebagai perbuatan pengrusakan atau penghancuran terhadap berbagai objek, seringkali makhluk hidup, dengan tujuan supranatural. Pengertian lainnya dikutip Eller dari pandangan para ahli, di antaranya adalah Durkheimian yang mendefinisikan pengorbanan sebagai mediasi antara domain sakral dan profan yang direpresentasikan oleh pelaku pengorbanan dan entitas supranatural yang dikorbankannya. Pandangan lain dikemukakan oleh E. B. Tylor yang melihat pengorbanan sebagai hadiah untuk Tuhan (Eller, 2007: 231).

Agama Hindu adalah agama pertama yang dikenal sebagai agama pengorbanan secara fundamental. Teks-teks Hindu awal seperti Veda secara prinsip mengandung instruksi pengorbanan. Dewa Agni (tuhan api), disebut sebagai "penguasa" pengorbanan. Orang Yunani Kuno melakukan pengorbanan hewan, seperti buphonia atau persembahan kerbau untuk Zeus. Adapun tujuan pengorbanan oleh masyarakat Yunani, sebagaimana dikemukakan Dennis Hughes, adalah untuk dipersembahkan kepada dewa-dewa Olympus, untuk pernikahan, persalinan dan pemakaman, untuk menghormati pahlawan, persiapan untuk pertempuran, sebagai bagian dari sumpah-sumpah, dan lain-lain. Bahkan dalam ritual farmakos, manusia dijadikan objek pengorbanan, seperti dicambuk, dikutuk, dan diusir dari kota karena dianggap membawa sial atau penyakit bagi komunitas mereka. Pengorbanan, oleh masyarakat tertentu, dianggap sangat penting untuk mempertahankan kekuasaan makhluk gaib, peran sosial (seperti raja), dan lain-lain (Eller, 2007: 231).

\subsubsection{Kemartiran/Kesyahidan}

Bentuk kekerasan yang paling sempurna yang dilakukan atas kehendak sendiri adalah kemartiran, bunuh diri, atau membiarkan diri sendiri menderita atau mati demi agama. Tindakan seperti ini bisa dikatakan sebagai pengorbanan diri. Droge dan Tabor menjelaskan bahwa kemartiran dalam tradisi Kristen dianggap sebagai tindakan yang benar. Pada abad-abad pertama kekristenan, panggilan menjadi martir adalah sebuah cita-cita. Oleh karena itu, orang-orang Kristen berusaha memberi kesaksian iman, menjalankan iman dengan sungguh-sungguh di hadapan orang-orang yang tidak beriman. Bahkan mereka rela jika kesaksian itu menuntut harga yang mahal, yaitu nyawa mereka sendiri, sebagaimana yang pernah dilakukan Yesus. Bapa Gereja melihat kemartiran bukan hanya sebagai satu-satunya jalan menuju keselamatan tetapi juga sebagai pilihan yang agung dan mulia, dengan ungkapan bahwa "penghukuman akan memberikan kita lebih banyak kesenangan daripada kebebasan" (Droge, 1992: 136). Origen menganggap kemartiran sebagai semacam ritual baptisan yang bisa menghapus dosa. Sedangkan Cyprian berpendapat bahwa "kematian membuat hidup lebih lengkap, kematian lebih mengarah kepada kemuliaan" (Smith, 1997: 91).

Dalam pandangan Eller, Islam memiliki tradisi kemartiran yang dikenal dengan istilah syahid. Istilah ini ditemukan dalam Q.S. 4: 69, yang artinya, "Dan barangsiapa yang mentaati Allah dan Rasul(Nya), mereka itu akan bersama-sama 
dengan orang-orang yang dianugerahi nikmat oleh Allah, yaitu Nabi-nabi, para shiddiqin, orang-orang yang mati syahid, dan orang-orang saleh. Dan mereka itulah teman yang sebaik-baiknya."

Kemartiran dalam Islam disebut dengan syahadah dan seorang martir disebut dengan syahid, yaitu orang yang mati karena memberi kesaksian dalam membela agama. Mengutip pendapat Ayatullah Sayyed Mahmud Taleqani, Eller menjelaskan bahwa Syahid adalah orang yang telah mengalami syuhud (penglihatan) kebenaran. Yang demikian adalah pengorbanan hidupnya sendiri, tidak didasarkan pada ilusi atau agitasi dari emosinya. Dia telah melihat kebenaran dan tujuan. Itulah mengapa dia memilih berkubang dalam darah dan debu. Orang yang mengorbankan dirinya sendiri seperti itu adalah dengan tujuan untuk menciptakan keintiman dengan Tuhan, bukan atas dasar fantasi dan keinginan pribadi. Dia berada di atas dunia ini adalah hal yang penting. Dia telah memahami nilai kebenaran dengan cara yang benar. Inilah mengapa dia memusnahkan dirinya, seperti setetes lautan kebenaran (Eller, 2007: 239).

Dalam tradisi Yudaisme, tidak ditemukan terminologi khusus untuk menyebut kemartiran, namun mengenal istilah profesi iman akan Tuhan Yang Esa, yaitu kesetiaan tanpa batas kepada Tuhan dalam kesaksian hidup sehari-hari yang membuat mereka lebih suka mati dalam cara apa pun daripada mengingkari atau menyangkal hukum Tuhan (Riyanto, 2010: 423).

Berdasarkan paparan di atas, dapat dipahami bahwa tradisi kemartiran atau kesyahidan dalam agama-agama merupakan ekspresi terdalam dari manusia yang ingin menampilkan konsep-konsep perjuangan dan kesetiaan kepada tuhan yang diimaninya. Mereka rela mengorbankan dirinya, bahkan nyawanya, demi agama yang mereka Imani.

\subsubsection{Perang Suci}

Perang suci adalah serangkaian perang yang mengatasnamakan agama.
Dalam tradisi agama-agama, fenomena perang suci seringkali dikaitkan dengan agama Islam dan Kristen. Oleh banyak kalangan, perang suci dalam Islam diidentikkan dengan istilah jihad, sedangkan dalam Kristen disebut dengan perang salib (crusade). Perang suci pada akhirnya menjadi agama universal, yang bukan hanya sekedar cara untuk mempertahankan kebenaran yang diyakini, tetapi malah menjadi objek kompetisi dengan agama lain. Eller mengatakan, tanpa bermaksud merendahkan, meskipun konsep Kristen tentang crusade kurang lebih sama dengan jihad, tetapi Islam dikenal sebagai agama yang paling dekat dengan asosiasi kekerasan dengan doktrin jihad mereka (Eller, 2007: 239).

Pandangan Eller yang menyamakan crusade dengan jihad menurut hemat penulis tidaklah tepat, karena secara historis aksi jihad dalam tradisi Islam tidak bertujuan untuk mengislamkan non-muslim, tetapi lebih sering dilakukan atas dasar politik, seperti perluasan wilayah Islam atau pembelaan umat Islam terhadap serangan dari luar. Sementara perang suci dalam tradisi Kristen bertujuan untuk misionaris.

Konsep perang dalam Islam dan Kristen, menurut Ellet, dapat dilacak dari doktrin Ibrani kuno yang disebut milhemet mitzvah, yaitu kewajiban perang. Milhemet mitzvah juga diizinkan untuk mempertahankan diri, untuk mencegah serangan. Memperluas wilayah kekuasaan Tuhan dianggap sebagai sebuah kewajiban. Dalam sejarah Islam, perang kuno di Ibrani pertama-tama dimaksudkan untuk menawarkan perdamaian kepada pihak lawan, jika penawaran ini diterima berarti mereka harus tunduk dan bersedia diperbudak oleh penyerangnya. Jika mereka menolak "tawaran damai," maka tentara yang salih dapat menghancurkan pihak lawan atau memperbudak mereka. Demikianlah perang suci dimaksudkan untuk menjaga keutuhan agama dan terbebas dari pengaruh asing. Eller memberikan contoh peperangan yang dikategorikan sebagai perang suci, di antaranya adalah 
perang saudara berbasis agama yang terjadi selama 30 tahun (1618-1648) antara Kristen melawan Kristen, Katolik melawan Protestan. Selama periode perang agama ini, diperkirakan 8 juta orang Eropa yang kehilangan nyawa (Eller, 2007: 239).

Konsep jihad dalam tradisi Islam, oleh kalangan tertentu, dipahami sebagai seruan berperang melawan kaum Kristiani. Padahal sebenarnya konsep perang dalam Islam merupakan tindakan defensif untuk mempertahankan diri dari serangan dari luar, bukan konsep yang represif untuk menyerang. Di dalam agama Hindu, perang merupakan deviasi dari norma-norma masyarakat yang ada, tetapi untuk menciptakan semesta makna akan kebenaran yang dikonsepkan dalam agama Hindu, terkadang perang menjadi suatu keharusan yang mesti dilakukan. Misalnya dalam kisah-kisah Mahabharata dan Ramayana, digambarkan betapa peperangan merupakan suatu episode tersendiri yang diungkapkan secara eksplisit. Meskipun demikian, hal demikian bukanlah sebuah ajaran yang harus dilakukan melainkan sebuah artikulasi dari penjabaran yang luas dari kebenaran ajaran Hinduisme (Hamsah, 2012).

Eller memandang Islam sebagai agama yang paling sering dianggap sebagai model perang suci, tetapi Eller memahami jihad, kata yang dikenal umum untuk perang suci, sebenarnya tidak berarti "perang" (qital). Jihad, menurutnya, adalah "perjuangan," termasuk apa yang disebut "jihad yang lebih besar" perjuangan melawan diri sendiri yang tidak bermoral dan "jihad yang lebih kecil" - jihad dengan pedang - perjuangan melawan musuh agama. Berbeda dengan Eller, Azyumardi Azra, merujuk tulisan Rudolph Peter yang mengutip pendapatnya al-Banna bahwa jihad dapat dikategorikan menjadi dua bagian, yaitu jihad yang bernuansa revolusioner sebagai metode yang absah untuk meraih cita-cita Islam dan jihad yang secara apologetik bertujuan untuk membuktikan bahwa Islam bukanlah agama kekerasan dan perang (Azra, 1994: 80-81).
Justifikasi kekerasan dalam tradisi Islam dengan memakai sejumlah ayat yang berkenaan dengan jihad atau qitāl (perang melawan kaum kafir) banyak kita jumpai. Sebagai contoh ayat yang dijadikan legitimasi untuk berjihad adalah Q.S alTaubah [9]:29 yang artinya sebagai berikut.

"Perangilah orang-orang yang tidak beriman kepada Allah dan tidak (pula) kepada hari kemudian, dan mereka tidak mengharamkan apa yang diharamkan oleh Allah dan Rasul-Nya dan tidak beragama dengan agama yang benar (agama Allah), (yaitu orang-orang) yang diberikan Al-Kitab kepada mereka, sampai mereka membayar jizyah dengan patuh sedang mereka dalam keadaan tunduk."

Ayat tersebut seringkali dikutip oleh kaum pelaku jihad di kalangan umat Islam untuk membenarkan tindakan terorisme. Padahal ayat ini berkenaan dengan perintah kepada Nabi Muhammad untuk memerangi orang-orang Kristen, setelah kekuatan orang-orang Arab yang menentang Islam ditaklukkan. Sejak ayat ini, dimulailah ekspedisi perang melawan kekuasaan Romawi dalam sejarah Islam (Abdalla, 2013).

\subsubsection{Konflik Etno-Religius}

Sebagai fenomena sosial, agama selalu bersentuhan dengan berbagai identitas dan kepentingan. Ketika kepentingan suatu kelompok agama diganggu, konflik dan kekerasan tentu akan terpercik. Meski demikian tak dapat disimpulkan dengan tergesa-gesa bahwa agamalah penyebab konflik tersebut. Agama seringkali dijadikan sebagai pembungkus kelompok-kelompok yang bertikai dan bukanlah poin utama penyebab kekacauan dalam masyarakat. Kebetulan saja, kelompok-kelompok yang berperang berbeda agamanya.

Kekerasan antar etnis pada umumnya terjadi ketika suatu etnis atau kelompok mengalami kekecewaan yang mendalam dan timbulnya rasa identitas yang sangat kuat 
pada komunitas mereka, kemudian simbolsimbol budaya etnis atau kelompok dijadikan sarana untuk melakukan gerakan yang mengarah pada kekerasan. Perasaan frustasi pada diri mereka akan menjadi gerakan yang mengarah pada kekerasan, yaitu ketika terjadi mobilisasi terhadap simbol-simbol budaya etnis atau kelompok untuk membakar psikologi individu-individu yang menjadi bagian atau terikat oleh identitas kelompok tersebut, sehingga anggota kelompok itu dengan mudah mengorbankan dirinya sebagai bagian dari gerakan tersebut (Mas'ud, 2001: 7-9).

Sebagai contoh, kekerasan yang dilakukan oleh Israel terhadap penduduk Palestina, di mana keturunan Yahudi menggunakan doktrin promised land sebagai legitimasi kekerasan terhadap penduduk non-Yahudi. Bentuk kekerasan langsung seperti pembunuhan, pengusiran, penahanan terjadi. Demikian juga kekerasan struktural seperti pelabelan penduduk kelas kedua terhadap non-Yahudi, pembatasan hak-hak sipil, peminggiran berjalan secara terstruktur dengan landasan keyakinan tentang "orang-orang terpilih yang memiliki hak atas tanah yang dijanjikan" (Soehadha, 2014).

Jack D. Eller mengatakan bahwa agama adalah elemen dalam sejumlah "konflik etnis," terutama abad ke-20 dan awal abad ke-21. Katolik versus Protestan di Utara Irlandia; Kristen versus Muslim di Bosnia; Hindu dan Muslim versus Sikh di Kashmir; Hindu versus Buddha di Sri Lanka; Sunni versus Syiah di Irak - dalam semua kasus-kasus ini, pihak yang berperang dibedakan oleh agama. Namun, akan lebih tepat untuk melihat konflikkonflik ini sebagai benturan masyarakat dan identitas kelompok kepentingan daripada agama. Sebagai contoh, kekerasan sektarian terjadi sejak1969 di Irlandia Utara, di mana Protestan dan Katolik terkunci dalam kekerasan secara nasional mendekati perang saudara selama hampir tiga dekade, tetapi bukan karena persoalan agama (Eller, 2007: 241).
Di Timur Tengah, ketegangan antara orang Yahudi dan umat Islam telah bergolak sejak abad ke-19, ketika orang Yahudi mulai berimigrasi untuk menduduki kembali tanah air historis mereka. Ketika negara Israel didirikan, wilayahArab Muslim melancarkan kampanye untuk menghancurkan negara tersebut, yang mengarah pada serangkaian peperangan dan pembentukan berbagai kelompok ekstremis, seperti Organisasi Pembebasan Palestina, Hamas, dan Hezbollah, yang didedikasikan untuk penghancuran Israel. Dalam kasus ini tampak jelas bahwa masalah kedaulatan, wilayah, kekayaan, dan kekuatan politik telah bercampur dengan perbedaan agama dan kebencian (Eller, 2007: 241).

Di Sri Lanka, ketika memperoleh kemerdekaan tahun 1948, telah terjadi konflik etnis antara etnis mayoritas Sinhala yang penduduknya beragama Buddha dan etnis minoritas Tamil yang sebagian besar adalah pemeluk agama Hindu. Salah satu penyebab timbulnya konflik etnis adalah karena pemerintahan baru Sri Lanka yang didominasi etnis Sinhala menjalankan berbagai kebijakan yang cenderung diskriminatif terhadap etnis Tamil. Kebijakan-kebijakan tersebut antara lain; menetapkan Sri Lanka sebagai Negara kesatuan, bukan Negara federal sebagaimana yang diinginkan komunitas Tamil; mengesahkan bahasa Sinhala sebagai bahasa nasional; mengesahkan agama Buddha sebagai agama resmi Negara. Persoalan semakin memburuk ketika komunitas Sinhala mengklaim diri mereka sebagai penduduk asli pulau tersebut dan direstui oleh Sang Buddha sendiri, sedangkan komunitas Tamil dianggap sebagai penjajah. Konflik antar etnis terus berlanjut dan tidak kunjung terselesaikan, perjuangan menuntut keadilan dan kesetaraan telah memunculkan gerakan yang mendukung "Negara Tamil" terpisah dari Sri Lanka (Eller, 2007: 242).

Gambaran konflik etno-religius di atas menunjukkan bahwa kekerasan dan konflik antar umat beragama dalam masyarakat pada perinsipnya bukan karena 
persoalan agama ansich, tetapi lebih sering dipicu oleh faktor lain seperti terdapat perbedaan strafikasi sosial politik dan ekonomi antarpemeluk agama. Perbedaan yang cukup senjang ini dapat menimbulkan kecemburuan sosial yang dapat memicu timbulnya kekerasan.

\subsubsection{Pelecehan, Kejahatan, dan Pembunuhan}

Dalam pandangan Eller, kekerasan agama dapat ditemukan dalam bentuk pelecehan, kejahatan dan pembunuhan. Menurutnya, tidak setiap penyalahgunaan, kejahatan, dan pembunuhan yang dilakukan oleh orang yang beragama adalah kejahatan agama. Bahkan bisa dikatakan bahwa hampir semua kejahatan bukanlah kejahatan agama. Banyak dijumpai orang yang religius melakukan pelanggaran dan kejahatan. Hal demikian terjadi bukan karena mereka yang religius tetapi karena mereka adalah pelaku dan kriminal. Seperti kasus skandal pelecehan seksual terhadap anak di beberapa Gereja Katolik dengan motif agama, oleh pelakunya tidak dianggap sebagai pelanggaran atau kejahatan, tetapi dianggap sebagai tindakan yang baik. Hal ini menunjukkan bahwa kejahatan yang dilakukan orang yang beragama itu tidak ada hubungannya dengan religiuitasnya, tetapi karena moral pelakunya yang tidak baik.

Contoh kasus kejahatan lainnya yang lebih mengerikan, sebagaimana yang dikemukakan Eller, adalah pembunuhan terhadap anak-anak yang dilakukan oleh ibu kandung mereka. Andrea, seorang wanita Texas yang membunuh lima anaknya pada tahun 2001, menyatakan bahwa motivasinya membunuh anak-anaknya adalah karena agama. Andrea berargumen bahwa anakanak mereka itu bukan anak-anak yang baik, karena dia tidak mendidiknya dengan baik, bahkan mereka terpengaruh oleh keburukan dan kejahatannya. Untuk menyelamatkan mereka dari siksa api neraka adalah dengan membunuhnya dengan cara mengikat leher mereka dan melemparkannya ke sungai. Sedangkan dalam masyarakat Muslim, gadis-gadis paling sering menjadi obyek penyalahgunaan agama dalam kekerasan, misalnya dalam "pembunuhan demi kehormatan" karena melakukan perbuatan yang melanggar agama, seperti berzina, berpacaran/menikah dengan pasangan di luar agama atau etnisnya (Eller, 2007: 244245).

Paparan di atas menunjukkan bahwa pelecehan, kejahatan, dan pembunuhan dengan motif agama itu benar-benar nyata. Budaya kekerasan semacam ini tentu bukanlah bagian dari ajaran agama. Agama disalahgunakan oleh pemeluknya untuk melakukan kekerasan, sekalipun oleh orang yang memiliki kapasitas keagamaan yang memadai.

\section{Penutup}

Dalam perspektif antropologi, Jack Davis Eller memahami tindak kekerasan itu bersifat subyektif, tergantung orang yang melihatnya. Sebagian kekerasan dianggap sebagai tindakan yang benar, dilegitimasi oleh agama dan sosial. Kajian mengenai antropologi kekerasan agama yang diintrodusir oleh Jack Davis Eller cukup komprehensif. Hal ini berbeda dengan kajian kekerasan agama yang disajikan penelitipeneliti sebelumnya yang terbatas pada agama Kristen dan Islam.

Eller menyuguhkan kepada kita suatu kenyataan bahwa kekerasan terjadi pada masyarakat di semua agama, bahkan dalam agama yang paling kecil sekalipun. Faktor pendukung timbulnya kekerasan agama sangat variatif; yaitu konstituen kekerasan budaya, integrasi ke dalam kelompok, identitas, institusi, minat, dan ideologi. Bentuk kekerasan agama yang dipaparkan Eller juga sangat variatif, mulai dari pengorbanan, kemartiran/kesyahidan, perang suci, konflik etno-religius, pelecehan, kejahatan, hingga pembunuhan dengan menggunakan justifikasi agama. Penelitian Eller ini berbeda dengan para ilmuwan lainnya yang kajiannya lebih banyak difokuskan pada bentuk kekerasan terorisme dan perang suci.

Menghubungkan agama dengan kekerasan adalah hal yang wajar. Hal ini 
karena agama telah menjadi bagian dari kehidupan masyarakat. Kekerasan pun sudah ada dalam kehidupan masyarakat. Sehingga jelaslah agama dan kekerasan pasti akan selalu terjadi. Dan tidak bisa dipungkiri bahwa di dalam setiap agama terdapat aspek-aspek yang mengandung unsur kekerasan, yang kemudian dipraktekkan oleh para pemeluknya untuk melakukan tindakan kekerasan kepada manusia lainnya dengan mendasarkan pada doktrin-doktrin agama tersebut. Namun realitanya, agama sering disalahgunakan untuk membenarkan tindakan kekerasan, yang sejatinya lebih sering dipicu oleh faktor personal, sosial, politik dan ekonomi.

\section{Daftar Pustaka}

Abdalla, Ulil Abshar. 2013. Kenapa Terjadi Kekerasan Atas Nama Agama?

www.suarakita.org/wpcontent/.../06/Kenapa-terjadikekerasan-atas-nama-agama.pdf,

Azra, Azyumardi. 1996. Pergolakan Politik Islam dari Fundamentalis, Modernisme Hinga Posmodernisme. Jakarta: Paramadina. 1994. "Jihad dan Terorisme: Konsep dan Perkembangan Historis" dalam Islamika, No. 4, April-Juni.

Baumeister, Roy. 2001. Evil: Inside Human Violence and Cruelty. New York: Barnes \& Noble.

Beuken, Wim dan Kuschel, Karl-Josef et.al. 2003. Agama Sebagai Sumber Kekerasan? Terj. Imam Baehaqi. Yogyakarta: Pustaka Pelajar.

Droge, Arthur J. and James D. Tabor. 1992. A Noble Death: Suicide and Martyrdom Among Christians and Jews in Antiquity. New York: Harper.
Eller, Jack David. 2007. Introducing Anthropology of Religion. New York: Rouledge.

Freud, Sigmund. 1968. The Standard Edition of the Complete Psychological Works of Sigmund Freud. Vol. XXI: The Future of Illusion (1927), trans. James Strachey, London: Hogarth Press.

Hamsah, Ustadi. Perang dan Kekerasan atas Nama Agama dalam Wacana Ilmiah, ESENSIA, Jurnal Ilmu-Ilmu Ushuluddin. Vol. VIII, No. 1, Januari.

Isnaeni, Ahmad. 2014. Kekerasan Atas Nama Agama, Kalam: Jurnal Studi Agama dan Pemikiran Islam, Volume 8, Nomor 2, Desember.

Juergensmeyer, Mark. 2000. Terror in the Mind of God: The Global Rise of Religious Violence, Berkeley: University of California Press.

Mas'ud, Mohtar, Mochammad Maksum, dan Moh. Soehadha (ed.). 2001. Kekerasan Kolektif; Kondisi dan Pemicu. Yogyakarta: P3PK UGM.

Ranstorp, Magnus. 2003. "Terrorism in the Name of Religion," in Russell D. Howard and Reid L. Sawyer (eds) Terrorism and Counterterrorism: Understanding the New Security Environment, Guilford, Conn.: McGraw-Hill/Dushkin, pp. 121-36.

Riyanto, Armada. 2010. Dialog Interreligius: Historitas, Tesis, Pergumulan, Wajah. Yogyakarta: Kanisius.

Scheper-Hughes, Nancy and Philippe Bourgois (eds). 2004. Violence in War and Peace: An Anthology. Oxford: Blackwell.

Simmel, George. 1955. Conflict and the Web of Group-Affiliations. New York: The Free Press. 
Smith, Lacey Baldwin. 1997. Fools, Martyrs, Traitors: The Story of Martyrdom in The Western World. New York: Alfred A. Knopf.

Soehadha, Moh. 2014. Kekerasan Kolektif Dan Dialog Kebudayaan: Belajar Dari Pengalaman Kekerasan Menjelang Reformasi di Indonesia. ESENSIA, Jurnal Ilmu-Ilmu Ushuluddin. Vol. 15. No.1.

Sumbulah, Umi. 2005. Agama dan Kekerasan: Menelisik Akar Kekerasan dalam Tradisi Islam. Studia Philosophica et Theologica. Vol. 5, No.1.

Zimbardo, Philip (2000). "The Psychology of Evil," Psi Chi 5 (1): 16-19. 